\title{
Abnormal p38 mitogen-activated protein kinase signalling in human and experimental diabetic nephropathy
}

\author{
L. Adhikary ${ }^{1}$ - F. Chow $^{1,2}$ • D. J. Nikolic-Paterson ${ }^{1,2}$ • C. Stambe ${ }^{1}$ J. Dowling ${ }^{3}$ R. C. Atkins ${ }^{1,2}$ • G. H. Tesch ${ }^{1,2}$ \\ ${ }^{1}$ Department of Nephrology, Monash Medical Centre, Clayton, Victoria, Australia \\ ${ }^{2}$ Monash University Department of Medicine, Monash Medical Centre, Clayton, Victoria, Australia \\ ${ }^{3}$ Department of Anatomical Pathology, Monash Medical Centre, Clayton, Victoria, Australia
}

\section{Abstract}

Aims/hypothesis. Inflammation and fibrosis are pathological mechanisms that are partially regulated by cell signalling through the p38 mitogen-activated protein kinase (MAPK) pathway. Elements of the diabetic milieu such as high glucose and advanced glycation endproducts induce activation of this pathway in renal cells. Therefore, we examined whether p38 MAPK signalling is associated with the development of human and experimental diabetic nephropathy.

Methods. Immunostaining identified phosphorylated (active) p38 MAPK in human biopsies with no abnormality $(n=6)$ and with Type 2 diabetic nephropathy $(n=12)$. Changes in kidney levels of phosphorylated p38 were assessed by immunostaining and western blotting in mice with streptozotocin-induced Type 1 diabetes that had been killed after $0.5,2,3,4$ and 8 months, and in Type 2 diabetic db/db mice at 2, 4, 6 and 8 months of age.

Results. Phosphorylated p38 was detected in some intrinsic cells in normal human kidney, including podocytes, cortical tubules and occasional interstitial cells. Greater numbers of these phosphorylated p38+ cells were observed in diabetic patients, and phosphorylated p38 was identified in accumulating interstitial macrophages and myofibroblasts. A similar pattern of p38 activation was observed in both mouse models of diabetes. In mice, kidney levels of phosphorylated p38 increased (2-6 fold) following the onset of Type 1 and Type 2 diabetes. In both mouse models, interstitial phosphorylated p38+ cells were associated with hyperglycaemia, increased $\mathrm{HbA}_{1} \mathrm{c}$ levels and albuminuria. Further assessment of streptozotocin-induced diabetic nephropathy showed that interstitial phosphorylated p38+ cells correlated with interstitial fibrosis (myofibroblasts, collagen).

Conclusions/interpretation. Increased p38 MAPK signalling is a feature of human and experimental diabetic nephropathy. Time course studies in mouse models suggest that phosphorylation of p38 plays a pathological role, particularly in the development of interstitial fibrosis.

Keywords $\mathrm{db} / \mathrm{db}$ mice $\cdot$ Diabetic nephropathy . Human kidney $\cdot$ p38 MAPK $\cdot$ Streptozotocin
Received: 23 January 2004 / Accepted: 26 March 2004

Published online: 1 July 2004

C Springer-Verlag 2004

G. H. Tesch ( $)$

Department of Nephrology, Monash Medical Centre,

246 Clayton Road, Clayton, Victoria 3168, Australia

E-mail: gtesch@hotmail.com

Tel.: +61-3-95943534, Fax: +61-3-95943530

Abbreviations: ECL, enhanced chemiluminescence $\cdot$ MAPK, mitogen-activated protein kinase $\cdot \mathrm{p}$-p38, phosphorylated p38

\section{Introduction}

Diabetes is the main cause of renal failure worldwide [1]. Current treatments, including glycaemic and blood pressure control, can slow the development of disease but do not stop the progression to end-stage renal failure [2]. In order to identify new therapeutic targets for the treatment of diabetic nephropathy, it is important to gain a greater understanding of the mechanisms responsible for the disease.

Inflammation and fibrosis are common disease mechanisms involved in many forms of progressive 
renal injury, including diabetic nephropathy [3]. Cell signalling through the p38 mitogen-activated protein kinase (MAPK) pathway, involving dual phosphorylation of the Tyr-X-Thr motif of p38 MAPK [4], is known to play a role in both of these processes $[5,6$, $7,8]$. Specific inhibition of p38 MAPK signalling is effective in the treatment of human endotoxaemia, and in rat models of inflammatory renal disease, lung fibrosis and arthritis $[9,10,11,12,13]$. Therefore, it is important to identify whether phosphorylation (activation) of p38 MAPK signalling is associated with the development of diabetic nephropathy.

In vitro studies have shown that components of the diabetic milieu (high glucose and advanced glycation end-products) can activate p38 MAPK signalling in renal cells. Exposure to high glucose levels induces p38 MAPK phosphorylation in mesangial cells [14] and glycated albumin stimulates p38 MAPK phosphorylation in fibroblasts [15]. The diabetic milieu may also promote p38 MAPK phosphorylation in diabetic kidneys by inducing inflammation and cytokine production. Indeed, increased levels of TNF- $\alpha$ and TGF- $\beta 1$ have been detected in the serum or glomeruli of diabetic rodents $[16,17]$ and serum levels of these cytokines are increased in diabetic patients [18]. Furthermore, advanced glycation, glycoxidation and lipoxidation end-products can stimulate IL-1 and TNF- $\alpha$ production by macrophages $[19,20]$. IL- 1 and TNF- $\alpha$ are potent inducers of p38 MAPK in renal parenchymal cells $[6,21]$ and TGF- $\beta 1$ stimulates p38 MAPK phosphorylation in mesangial cells and fibroblasts $[7,8]$. Thus the diabetic milieu could potentially promote $\mathrm{p} 38$ MAPK phosphorylation in renal cells by direct and indirect pathways.

Induction of kidney p38 MAPK phosphorylation by the diabetic milieu may promote the development of renal fibrosis. Phosphorylation of p38 MAPK by hyperglycaemia and/or mechanical stretch promotes mesangial cell production of TGF- $\beta 1$ and fibronectin $[22,23]$. TGF- $\beta 1$ can, in turn, induce the synthesis of collagen and fibronectin by mesangial cells and fibroblasts via a p38-MAPK-dependent pathway [7, 8]. Consequently, p38 MAPK phosphorylation may play an important role in the development of renal fibrosis in diabetic nephropathy.

Previous work has identified phosphorylation of p38 MAPK in isolated glomeruli from the early stages of streptozotocin-induced diabetic nephropathy in the rat [24]. However, a number of issues regarding p38 MAPK signalling in diabetic nephropathy remain unknown, including (i) whether p38 MAPK phosphorylation is associated with diabetic renal injury; (ii) the cell types in which the pathway is activated; (iii) whether p38 signalling occurs in tubules or the interstitium; and (iv) how relevant p38 activation in disease models is to what happens in human diabetic nephropathy

In the current study, we assessed phosphorylation of p38 MAPK as a marker of p38 MAPK activation in renal biopsies of patients with Type 2 diabetic nephropathy and compared these results with renal function at the time of biopsy. We also examined the kidney localisation and levels of p38 MAPK phosphorylation, and its association with renal injury, during the progression of Type 1 and Type 2 diabetic nephropathy in mice.

\section{Subjects, materials and methods}

Human biopsies. All formalin-fixed renal biopsy tissue, both normal and diabetic, was obtained with patient consent and permission of the Monash Medical Centre Human Ethics Committee. Normal human kidney tissue (control subjects) was acquired when biopsies performed for minimal proteinuria $(<0.3 \mathrm{~g}$ /day $)$ or haematuria $\left(<25 \times 10^{3} / 1\right.$ urinary glomerular red cells) were reported to have no renal abnormality. Analysis was performed on biopsies from patients with Type 2 diabetic nephropathy (Type 2 diabetic subjects) as the only diagnosis (see Table 1). Standard histological criteria were used for the diagnosis of diabetic nephropathy, including the presence of diffuse basement membrane thickening, glomerulosclerosis with or without Kimmelstiel-Wilson nodules, efferent and afferent arteriolar hyalinisation and tubulointerstitial fibrosis.

Animal models. Type 1 diabetes was induced in male C57BL/6 mice (20-25 g) by intraperitoneal injection of $125 \mathrm{mg} / \mathrm{kg}$ streptozotocin (Sigma, St. Louis, Mo., USA) on two consecutive days. The blood glucose levels of streptozotocin-treated mice were maintained at 16 to $30 \mathrm{mmol} / \mathrm{l}$ by giving subcutaneous injections of human insulin $(0.4 \mathrm{U} /$ day Protophane, Novo Nordisk, Sydney, Australia) to mice when their blood glucose levels rose above $30 \mathrm{mmol} / \mathrm{l}$. We also studied Type 2 diabetic mice $(\mathrm{db} / \mathrm{db})$ and non-diabetic heterozygote control mice $(\mathrm{db} /+)$ that were created by breeding pairs of $\mathrm{C} 57 \mathrm{BL} / 6 \mathrm{db} /+$ mice obtained from Jackson Laboratories (Bar Harbor, Me., USA) and identified by PCR tissue type analysis for the leptin receptor. Mice were maintained on a normal diet under standard animal house conditions and were assessed every 2 weeks for blood glucose (glucometer) and every month for albuminuria. Groups of streptozotocin-treated mice $(n=5)$ were killed

Table 1. Clinical characteristics and treatments of patients at the time of biopsy

\begin{tabular}{lcc}
\hline & $\begin{array}{l}\text { Control } \\
\text { subjects } \\
(n=6)\end{array}$ & $\begin{array}{l}\text { Type } 2 \\
\text { diabetic subjects } \\
(n=12)\end{array}$ \\
\hline Age (years) & $45.2 \pm 2.4$ & $50.8 \pm 3.0$ \\
Duration of diabetes (years) & 0 & $6.4 \pm 1.8$ \\
$\mathrm{HbA}_{1} \mathrm{c}$ & $6.2 \pm 0.5$ & $8.6 \pm 0.4$ \\
Serum creatinine $(\mu \mathrm{mol} / \mathrm{l})$ & $71 \pm 7$ & $141 \pm 26$ \\
Creatinine clearance $(\mathrm{ml} / \mathrm{min})$ & $109 \pm 14$ & $67 \pm 9$ \\
Proteinuria $(\mathrm{g} / 24 \mathrm{~h})$ & $0.29 \pm 0.02$ & $3.6 \pm 0.8$ \\
Hypertension & 0 & $12 / 12$ \\
ACE inhibitor or AT2RA & 0 & $10 / 12^{\mathrm{a}}$ \\
HMG-CoA R inhibitor & 0 & $8 / 12$ \\
\hline
\end{tabular}

Data are means \pm SEM. AT2RA, angiotensin type 2 receptor antagonist; HMG-CoA R, 3-hydroxy-3-methyl-glutaryl coenzyme A reductase. a Two patients received beta blockers instead as anti-hypertensive therapy 
at $0.5,2,3,4$ and 8 months after injection. Groups of diabetic $\mathrm{db} / \mathrm{db}$ mice $(n=5)$ were killed at 2, 4, 6 and 8 months of age. A group of non-hyperglycaemic, obese $\mathrm{db} / \mathrm{db}$ mice $(n=5)$ was also examined at 8 months of age. A control group of normal C57BL/6 mice $(n=8)$ was killed at 8 months of age.

Biochemical analysis. Mouse urine was collected from animals housed in metabolic cages for $18 \mathrm{~h}$. Whole mouse blood was collected in the presence of heparin via cardiac puncture of anaesthetised mice. Triglycerides, cholesterol, $\mathrm{HbA}_{1} \mathrm{c}$, urine creatinine and plasma creatinine were analysed by the Department of Biochemistry at the Monash Medical Centre. Creatinine levels were determined by creatininase assay (Roche Diagnostics, Mannheim Germany). Mouse urine albumin was measured by ELISA kit (Bethyl Laboratories, Montgomery, Tex., USA).

For experiments with biopsies from humans, data for each patient were retrieved from hospital records, including data on serum creatinine, creatinine clearance, 24-hour urinary protein excretion at time of kidney biopsy, anti-hypertensive therapy, $\mathrm{HbA}_{1} \mathrm{c}$ and duration of diabetes.

Antibodies. The antibodies used in this study were: mouse antiphospho-p38 (Sigma, St Louis, Mo., USA) raised against the dual phosphorylated p38 (p-p38) peptide and recognising all the phosphorylated p38 isoforms; mouse anti-p38 $\alpha$ (Upstate Biotechnology, New York, N.Y., USA); rat anti-mouse CD68 (FA-11, Serotec, Kidlington, Oxford, UK); mouse anti-human CD68 (KP1, Dako, Carpinteria, Calif., USA); fluorescein-conjugated mouse anti- $\alpha$-smooth muscle actin (1A4, Sigma); mouse anti-human podocalyxin (PHM5, [25]); rabbit antimouse collagen IV (Collaborative Biomedical Products, Bedford, Mass., USA). Isotype-matched irrelevant IgGs were used as negative controls.

Immunohistochemical staining. Human and mouse tissue sections were immunostained using the same protocols. Immunostaining for p-p38 alone and dual-labelling of p-p38 with myofibroblasts ( $\alpha$-smooth muscle actin) or podocytes (podocalyxin) were performed on formalin-fixed kidney paraffin sections $(4 \mu \mathrm{m})$. The specificity of p-p38 labelling has been previously demonstrated by peptide blocking in our laboratory [11]. Dual-labelling of p-p38 with CD68+ macrophages was performed on kidney cryostat sections $(5 \mu \mathrm{m})$ fixed on $2 \%$ paraformaldehyde-lysine-periodate. Tissue sections were incubated for 20 min with $0.6 \%$ hydrogen peroxide to prevent detection of endogenous peroxidase and for a further 20 min with $20 \%$ normal sheep serum to prevent non-specific antibody binding. Sections were then incubated overnight at $4{ }^{\circ} \mathrm{C}$ with $5 \mu \mathrm{g} / \mathrm{ml}$ of primary antibody in $1 \%$ BSA. After washing in PBS, sections were incubated for $1 \mathrm{~h}$ with peroxidase-conjugated sheep antibodies against rat, mouse or rabbit $\operatorname{IgG}(1: 50$, Dako) or against fluorescein $(1: 300$, Roche), followed by rat, mouse, or rabbit peroxidase anti-peroxidase soluble complexes (1:50, Dako) for $1 \mathrm{~h}$. Sections were developed with 3,3-diaminobenzidine (Sigma) to observe peroxidase (brown) or with Vector SG substrate (Vector Laboratories, Burlingame, Calif., USA) to observe peroxidase (blue-grey). For antibody detection of p-p38, tissue sections were microwave-treated at $800 \mathrm{~W}$ for $12 \mathrm{~min}$ in $400 \mathrm{ml}$ of $10 \mathrm{mmol} / \mathrm{l}$ sodium citrate, $\mathrm{pH} 6.0$. To prevent antibody cross-reactivity and inactivate previously bound peroxidase-conjugated antibodies [26] in double-immunostaining, p-p38 was always the second antigen detected after microwave treatment. Following immunostaining, some sections were counterstained with periodic acid Schiff's reagent to identify kidney structure and tissue damage.
Quantitation of immunohistochemistry. The number of p-p38+ cells was counted under high power microscope (x400) within every glomerulus $(n=4-31)$ and the whole cortical tubulointerstitium (11-25 fields) of renal biopsies. In mouse kidneys, glomerular p-p38+ cells were counted in 20 hilar glomerular tuft cross-sections per animal. Mouse interstitial p-p38+ cells were counted, by means of a $0.02-\mathrm{mm}^{2}$ graticule fitted in the eyepiece of the microscope, in 25 consecutive interstitial fields (representing $30-40 \%$ of kidney cortex in the cross-section) and expressed as cells $/ \mathrm{mm}^{2}$. Interstitial expression of $\alpha$ smooth muscle actin and collagen IV in mice was assessed by computer image analysis as percentage of area stained within the renal cortex. All scoring was performed on blinded slides.

Western blotting. Whole mouse kidney (1/4) was homogenised in $0.5 \mathrm{ml} \mathrm{SDS}$-PAGE sample buffer for $1 \mathrm{~min}$ and heated to $100{ }^{\circ} \mathrm{C}$ for $5 \mathrm{~min}$. Samples were centrifuged at 14,000 $\mathrm{g}$ for $5 \mathrm{~min}$ and the supernatant stored at $-80^{\circ} \mathrm{C}$. Protein estimations were performed using a Bradford assay (Pierce, Rockford, Ill., USA). Kidney protein was loaded at $80 \mu \mathrm{g} /$ well and separated on a $12.5 \%$ SDS-PAGE gel. Gels were electroblotted on to a nitrocellulose membrane, and incubated for $2 \mathrm{~h}$ in $20 \mathrm{ml}$ of blocking buffer containing 5\% skimmed milk, $10 \%$ normal sheep serum and 1\% BSA in TBS (150 mmol/l $\mathrm{NaCl}$, $0.05 \mathrm{~mol} / \mathrm{l}$ Tris-HCl, $\mathrm{pH}$ 7.6). Blots were then washed in TBS-T buffer $(0.05 \%$ Tween 20 in TBS) and incubated overnight at $4{ }^{\circ} \mathrm{C}$ with anti-phospho-p38 antibody $(1 \mu \mathrm{g} / \mathrm{ml})$ in TBS-T containing 5\% BSA. After further washing, blots were incubated for $2 \mathrm{~h}$ at room temperature with peroxidase-conjugated goat anti-mouse IgG (1:20,000 in TBS-T containing 2\% BSA). Membranes were washed again and membrane-bound antibody detected by enhanced chemiluminescence (ECL) with Supersignal West Pico chemiluminescent substrate (Pierce) and captured on X-ray film. Following phospho-p38 detection, blots were analysed for equivalence of protein loading. Blots were incubated with $20 \mathrm{ml}$ of blocking buffer for $2 \mathrm{~h}$ and then overnight with fluorescein-conjugated anti- $\alpha_{1}$ tubulin (1:5000) in TBS-T containing $2 \%$ BSA. Membranes were washed, incubated for $30 \mathrm{~min}$ with alkaline phosphatase-conjugated sheep anti-fluorescein $\mathrm{F}(\mathrm{ab})$ fragments $(1: 10,000$ in wash buffer containing $2 \%$ BSA), washed again and membrane-bound antibody detected by ECL with CDP-Star substrate (Roche) and captured on X-ray film. Following $\alpha$-tubulin detection, blots were stripped with Re-Blot (Chemicon International, Temecula, Calif., USA) and re-probed with anti-p38 $\alpha$ antibody $(1 \mu \mathrm{g} / \mathrm{ml})$ using the same immunodetection conditions as described for phospho-p38. After capturing ECL images on film, densitometry analysis was performed using the Gel Pro analyser program (Media Cybernetics, Silver Spring, Md., USA).

Statistical analysis. Statistical differences between two groups were analysed by the unpaired Student's $t$ test and differences between multiple groups of data were assessed by ANOVA with Bonferroni's multiple comparison test using GraphPad Prism 3.0 (GraphPad Software, San Diego, Calif., USA). Correlations were performed using Pearson's correlation coefficient. Data were recorded as the mean \pm SEM and $p$ values of less than 0.05 were considered significant.

\section{Results}

Phosphorylation of p38 mitogen-activated protein kinase in normal human kidney. Immunostaining of normal human kidneys (control subjects) identified nuclear p-p38 in some glomerular visceral and parietal 

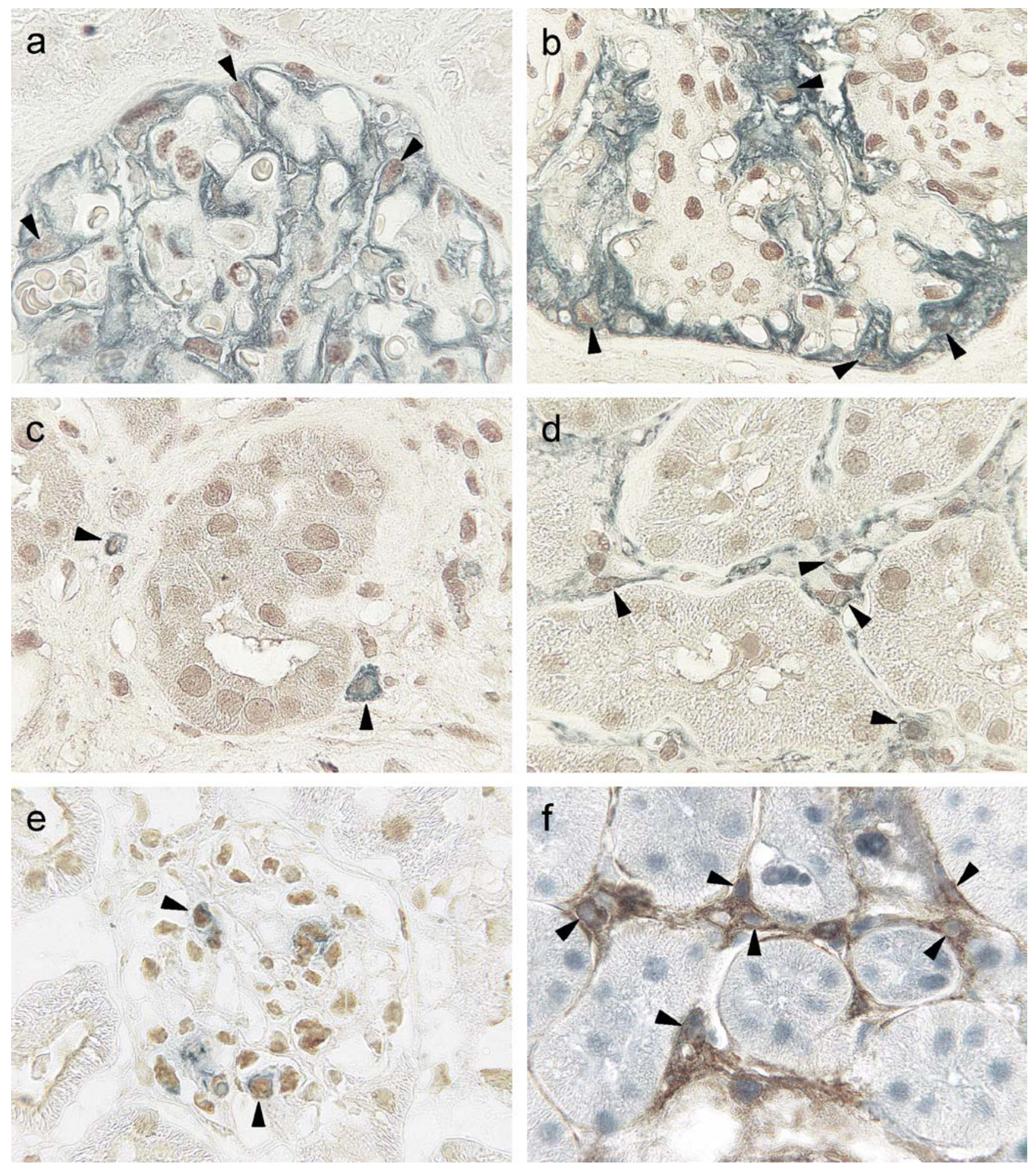

Fig. 1. Identification of p-p38+ kidney cells during diabetic nephropathy. Two-colour immunostaining of human biopsies identified podocytes (blue-grey) with p-p38 (brown nuclei, arrowheads) in glomeruli from control subjects (a) and glomeruli from Type 2 diabetic subjects (b). Increased numbers of cells positive for p-p38 immunostaining were seen in the mesangium of diabetic patients (b). In human diabetic kidneys, p-p38 (brown) was also detected (c) in interstitial CD68+ macrophages (blue-grey, arrowheads) and (d) in interstitial myofi-

broblasts expressing $\alpha$-smooth muscle actin (blue-grey, arrowheads). Similar immunostaining in mice identified p-p38 (brown) in CD68+ glomerular macrophages (blue-grey, arrowheads) (e) at 2 weeks after streptozotocin treatment. At 8 months after streptozotocin treatment, most interstitial p-p38+ cells (blue-grey) were found (f) to be myofibroblasts expressing $\alpha$-smooth muscle actin (brown, arrowheads). Magnification $\times 1000$ 


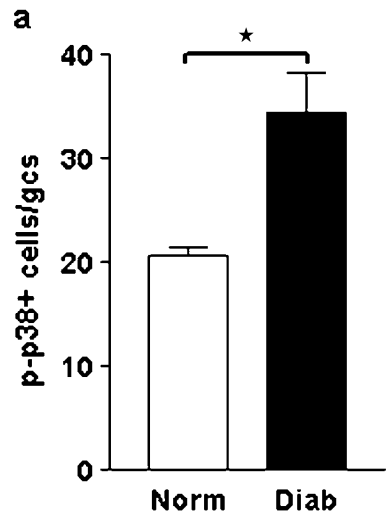

Fig. 2. Expression of p-p38 by kidney cells in human diabetic nephropathy. Immunostaining of human renal biopsies identified greater numbers of glomerular cells (a), tubular cells (b) and interstitial cells (c) expressing p-p38 in Type 2 diabetic kidneys than in normal kidneys. Data are means \pm SEM. Control subjects $(n=6)$, Type 2 diabetic subjects $(n=12) ; p$ values were determined by Student's $t$ test. * $p<0.05$; ** $p<0.01$; $* * * p<0.001$. Diab, diabetic kidneys; gcs, glomerular cross sections; Norm, normal kidneys

epithelial-like cells, occasional interstitial cells and in one or more cells of most cortical tubular cross-sections. Detection of p-p38 in podocytes in normal glomeruli was confirmed by double-immunostaining of p-p38 with podocalyxin (a podocyte marker) in biopsy specimens (Fig. 1a).

p38 mitogen-activated protein kinase signalling in human Type 2 diabetic nephropathy. The characteristics of Type 2 diabetic subjects from whom renal biopsies were examined for the number of p-p38+ cells are detailed in Table 1. Compared to normal human kidney, there was a two- to six-fold increase in the numbers of glomerular, tubular and interstitial cells positive for p-p38 immunostaining in human Type 2 diabetic kidneys (Fig. 2). The numbers of podocytes positive for p-p38 immunostaining increased as a result of diabetes (normal 5.4 \pm 0.6 vs diabetic 12.2 \pm 2.0 p-p38+PHM5+ cells per glomerular cross section, $p<0.0001)$. However, podocytes accounted for only a small proportion of total glomerular p-p38+ cells in normal $(27 \pm 4 \%)$ and diabetic $(22 \pm 5 \%)$ kidneys. Most of the p-p38+ cells seen within diabetic glomeruli were in the mesangium (Fig. 1b). Within the interstitium of diabetic kidneys, p-p38 was detected in some CD68+ macrophages $(30 \pm 5 \%)$ and myofibroblasts $(24 \pm 6 \%)$ (Fig. 1c, d), which was not observed in normal kidneys. Myofibroblasts accounted for the majority of interstitial p-p38+ cells in diabetic kidneys. The numbers of glomerular, tubular and interstitial p-p38+ cells did not correlate with proteinuria or renal function at the time of biopsy. However, this may well reflect the small number of biopsies available for examination and the variability in disease progression at the

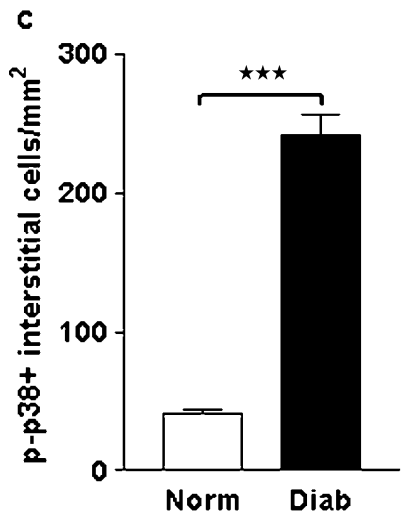

time of biopsy. For this reason, we examined mouse models of the disease in order to evaluate p38 phosphorylation in diabetic nephropathy in greater detail.

p38 mitogen-activated protein kinase phosphorylation in streptozotocin-induced diabetic nephropathy in mice. Western blotting identified a two- to three-fold increase in total kidney p-p38 after 2 weeks of streptozotocin-induced diabetes, coinciding with the onset of hyperglycaemia (Fig. 3a, c; Table 2). Total kidney pp38 levels increased to about six-fold above normal at 2 months after streptozotocin and were maintained at four- to five-fold of normal levels at 4 and 8 months after streptozotocin (Fig. 3a, c). Total kidney levels of p38 $\alpha$ showed a small (not significant) increase during disease (Fig. 3a, e). Comparison of p-p38 with p38 $\alpha$ identified a marked increase in the kidney p-p38 : p38 $\alpha$ ratio at 8 months after streptozotocin (Fig. 3g).

Immunostaining of normal mouse kidney showed a similar pattern of p-p38 to that in normal human kidney (Fig. 1a; Fig. 4a). After two weeks of streptozotocin-treatment, there was a two-fold increase in the number of glomerular and tubular cells positive for p-p38 immunostaining (Fig. 4b; Fig. 5a, b). Doubleimmunostaining for p-p38 and CD68 demonstrated that increased numbers of p-p38+ cells in glomeruli were due in part to infiltrating macrophages (Fig. 1e). Comparison of all timepoints showed that after 2 weeks of streptozotocin the number of glomerular and tubular cells positive for p-p38 immunostaining declined with the progression of diabetes and was not different from normal at 4 and 8 months after disease induction (Fig. 5a, b). In contrast, the number of interstitial cells positive for p-p38 immunostaining increased with the duration of disease and was six-fold greater than normal at 8 months after streptozotocin (Fig. 5c). Double-immunostaining for p-p38 and $\alpha$-smooth muscle actin showed that most of these p-p38+ interstitial cells were myofibroblasts (Fig. 1f).

p38 mitogen-activated protein kinase phosphorylation in diabetic nephropathy in $\mathrm{db} / \mathrm{db}$ mice. In $\mathrm{db} / \mathrm{db}$ mice, there was a two-fold increase in total kidney p-p38 levels detected by western blotting at 2 months of age. 


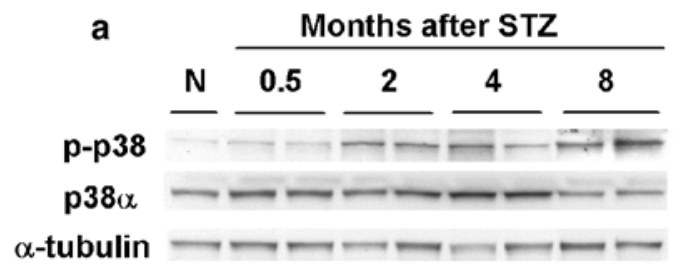

b $\mathrm{db} / \mathrm{db}$ mice - age in months
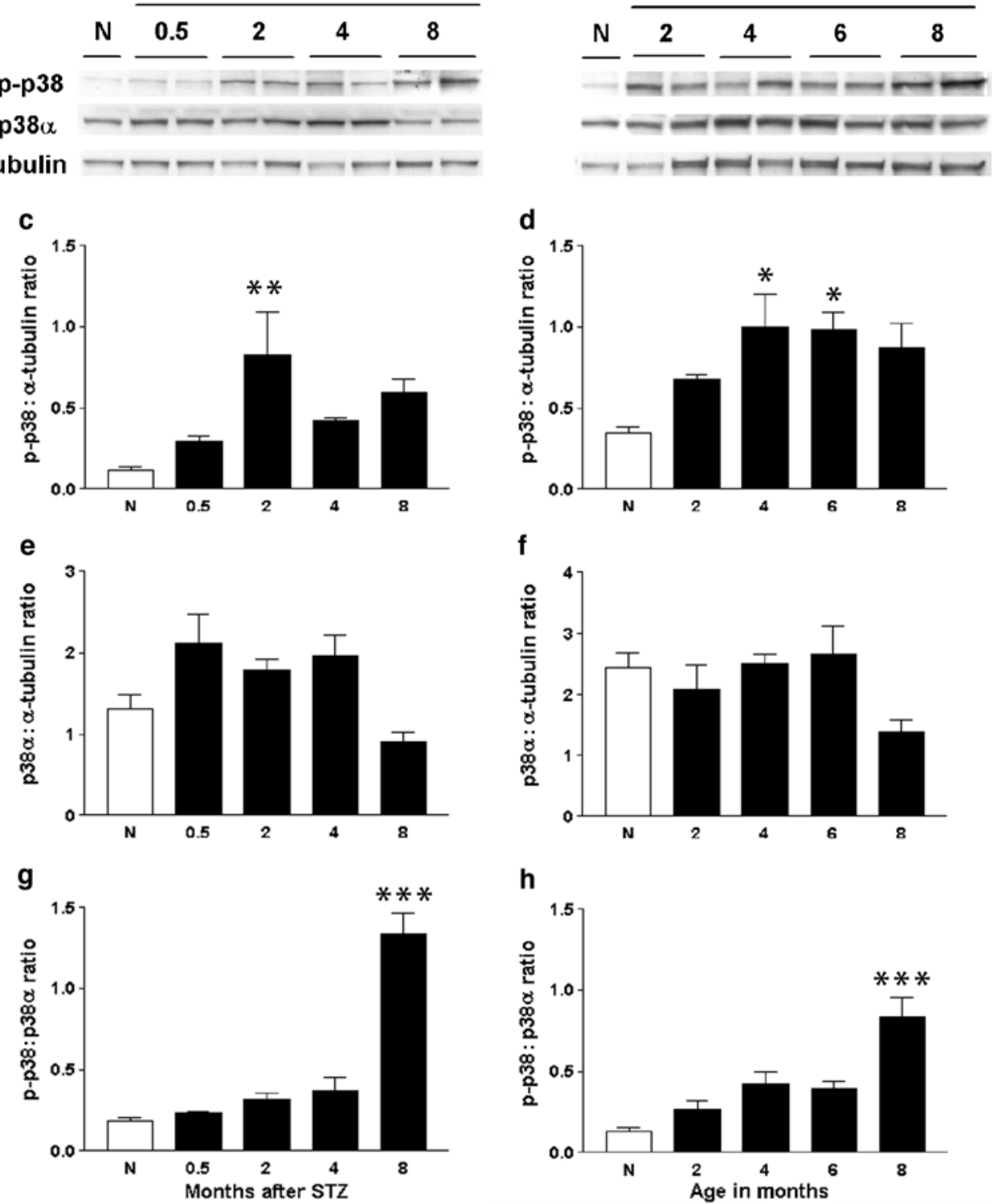

h

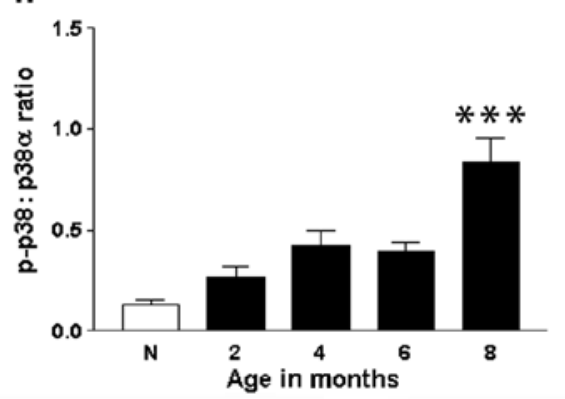

Fig. 3. Increased kidney phosphorylation of p38 MAPK during diabetic nephropathy. Western blots detected greater levels of $\mathrm{p}$ p38 in total kidney lysates from (a) streptozotocin (STZ)-treated diabetic mice and (b) db/db diabetic mice than in lysates from normal mice $(\mathrm{N})$. Kidney levels of $\alpha$-tubulin were used as a loading reference. Kidney levels of p-p38 increased rapidly during the early stages of diabetic nephropathy in STZ-treated mice (c) and db/db mice (d). In comparison, kidney levels of p38 $\alpha$ remained relatively unchanged throughout in STZ-treated mice (e) and $\mathrm{db} / \mathrm{db}$ mice (f). Comparison of p-p38 with $\mathrm{p} 38 \alpha$ levels showed a significant increase in the kidney p-p38:p38 $\alpha$ ratio in advanced stages of diabetic nephropathy in STZ-treated mice $(\mathbf{g})$ and $\mathrm{db} / \mathrm{db}$ mice $(\mathbf{h})$. Data are mean \pm SEM, $n=4$; $* p<0.05, * * p<0.01, * * * p<0.001$ vs normal by ANOVA

This increased to three-fold at 4 months of age when all mice became hyperglycaemic, and remained at a similar level at 6 and 8 months of age (Fig. 3b, d). In contrast, total kidney levels of $\mathrm{p} 38 \alpha$ were not different to normal throughout the development of diabetic neph-

ropathy (Fig. 3b, f). On comparing p-p38 with p38 $\alpha$, we found a marked increase in the p-p38:p38 $\alpha$ ratio in $\mathrm{db} / \mathrm{db}$ mouse kidneys at 8 months of age (Fig. 3h).

Immunostaining showed that the number of glomerular and tubular cells positive for p-p38 immunostaining increased progressively until 4 months of age and thereafter declined in glomeruli at 6 and 8 months and in tubules at 8 months (Fig. 4c, d; 5d, e). When the number of tubular p-p38+ cells in diabetic kidneys reached their peak, p-p38 immunostaining was most prominent in injured dilated tubules (Fig. 4e). As in the streptozotocin model, the number of interstitial cells positive for p-p38 immunostaining in $\mathrm{db} / \mathrm{db}$ Type 2 diabetic kidneys increased with disease progression, becoming four-fold higher than normal at 8 months of age (Fig. 4f; Fig. 5f). In comparison, obese $\mathrm{db} / \mathrm{db}$ mice that did not develop diabetes by 8 months of age had similar numbers of interstitial p-p38+ cells to normal mice (normal $=47 \pm 5$ cells $/ \mathrm{mm}^{2}$, normoglycaemic obese $\mathrm{db} / \mathrm{db}$ mice $=56 \pm 5$ cells $/ \mathrm{mm}^{2}$ ). 

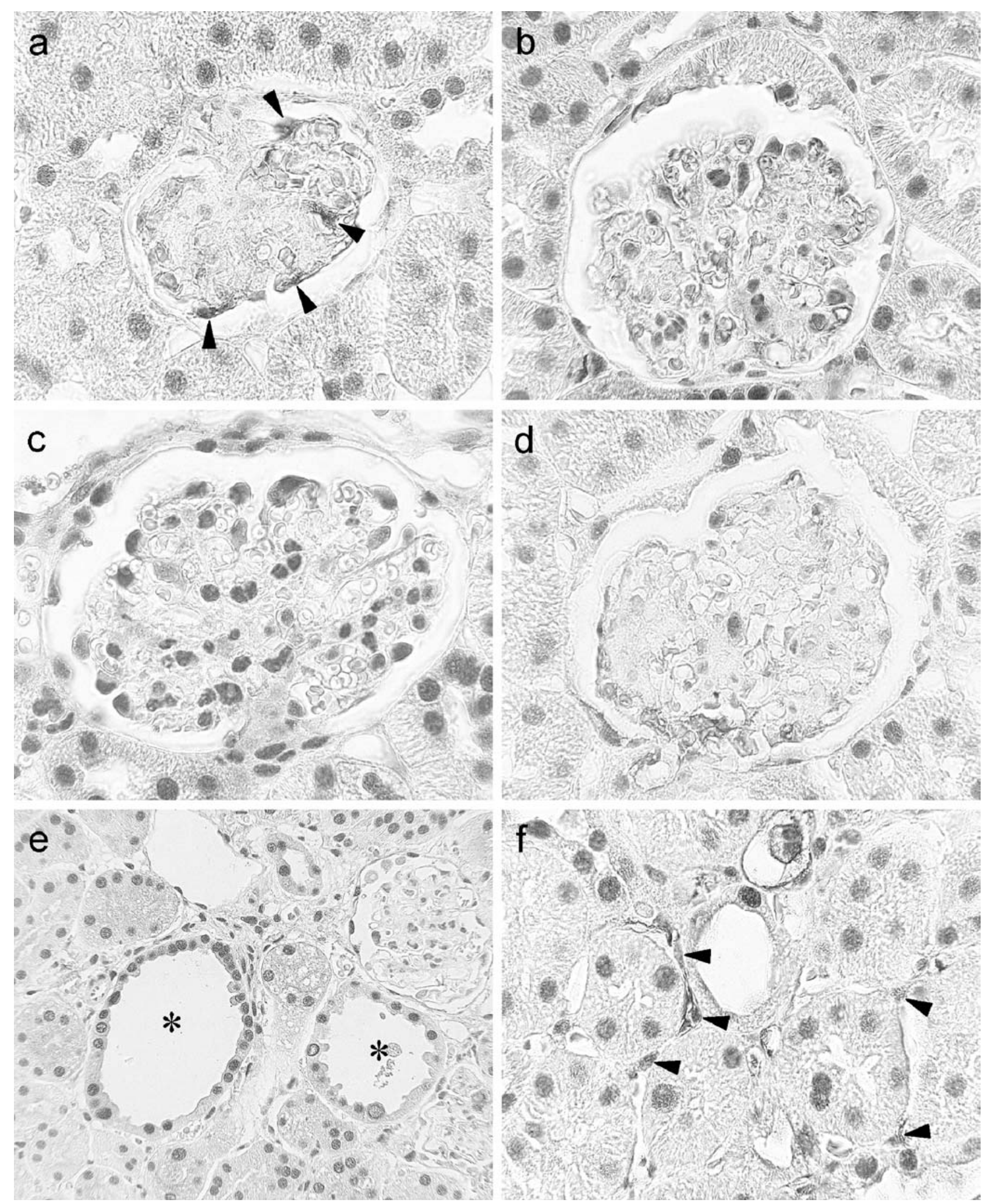

Fig. 4. Expression of phospho-p38 in normal and diabetic mouse kidneys. Immunostaining shows the presence of $\mathrm{p}-\mathrm{p} 38$ in (a) normal mouse glomeruli (arrowheads) and tubules, appearing to be mainly expressed by epithelial-like cells (glomerular podocytes and tubular cells). An increase in glomerular p-p38+ cells was seen at 2 weeks after streptozotocin administration (b) and in diabetic db/db mice at 2 months of age (c). The number of glomerular $\mathrm{p}-\mathrm{p} 38+$ cells in $\mathrm{db} / \mathrm{db}$ mice returned

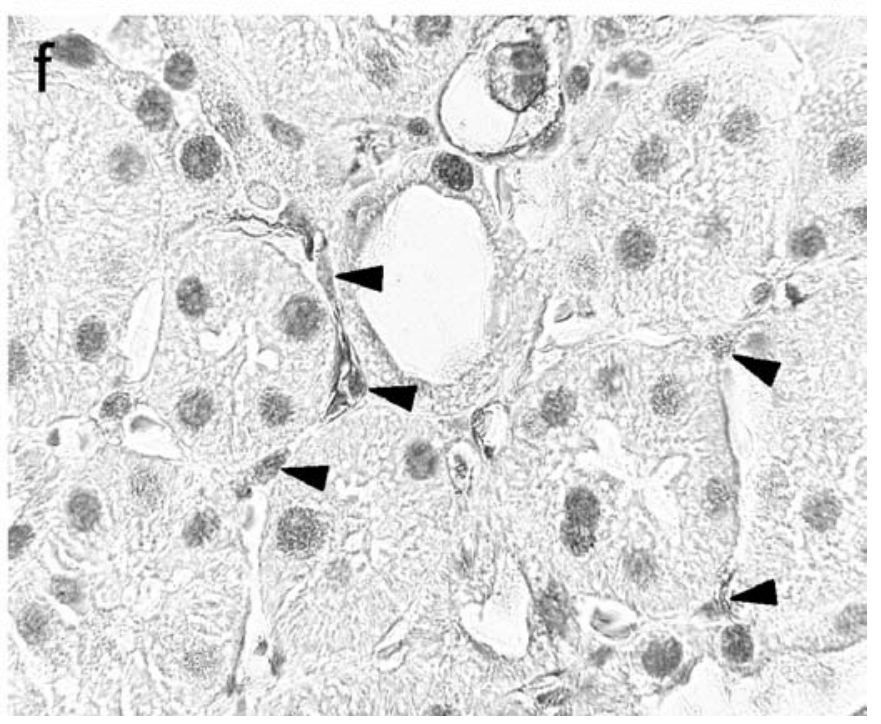

to normal levels (d) at 8 months of age. In a diabetic $\mathrm{db} / \mathrm{db}$ mouse kidney at 6 months of age (e), disease progression was associated with the dilation of some cortical tubules, which appeared to have an increased proportion of cells expressing p-p38 (*). The advancement of diabetic nephropathy also resulted in accumulation of interstitial cells expressing p-p38 (arrowheads) in a diabetic db/db mouse kidney (f) at 8 months of age. Magnification: $\times 1000$, except $(\mathbf{e}): \times 400$ 

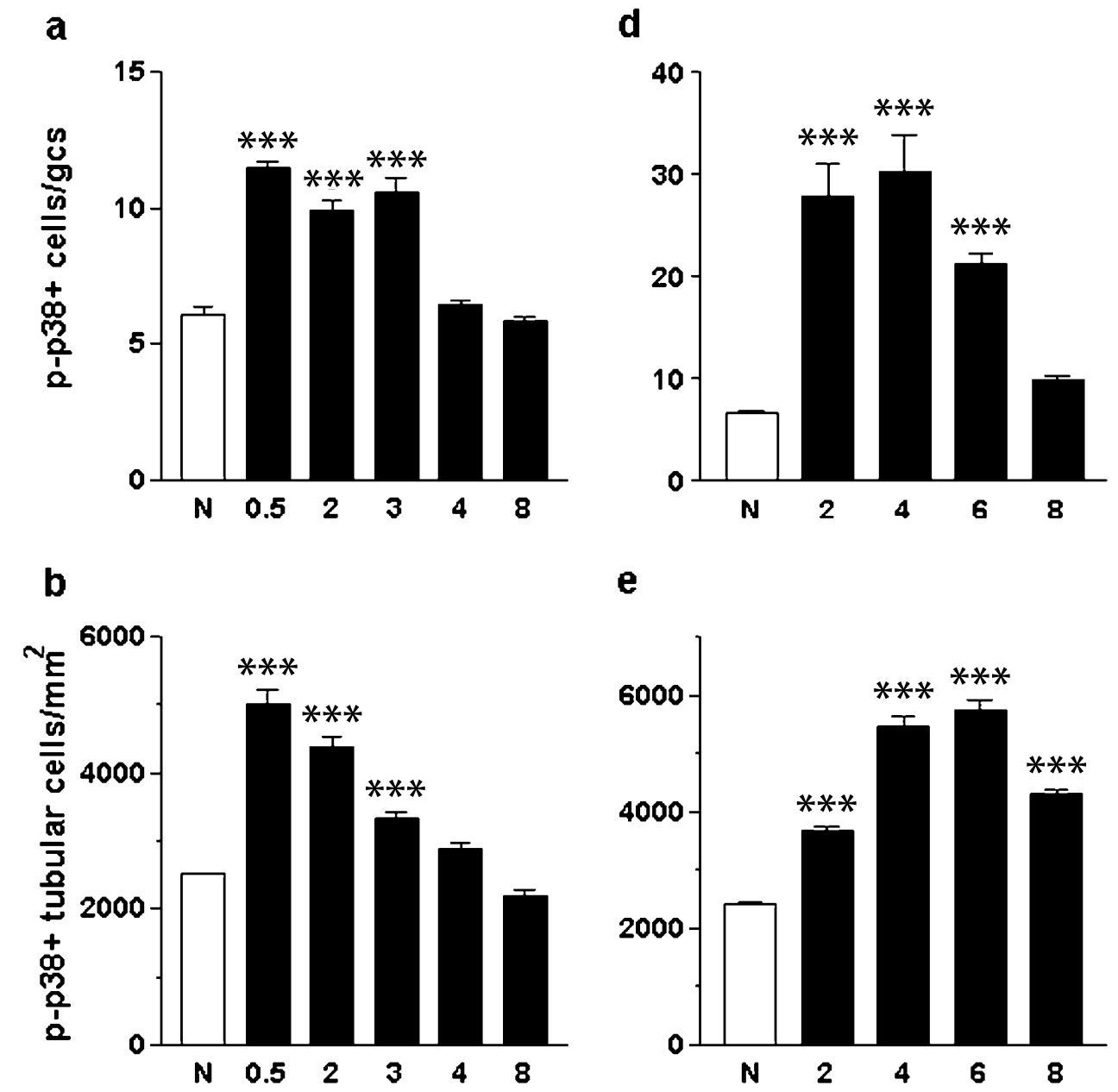

e
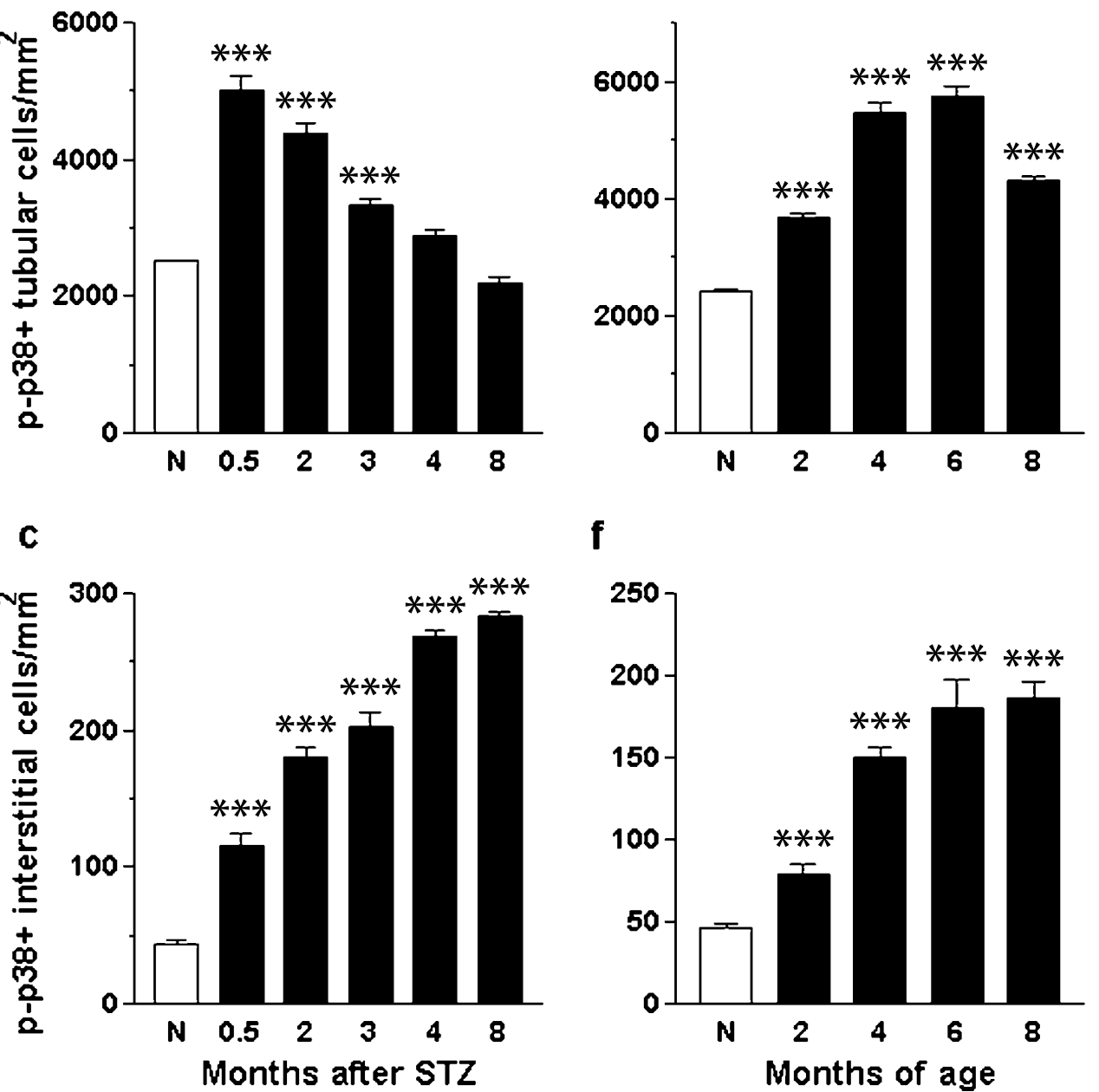

f

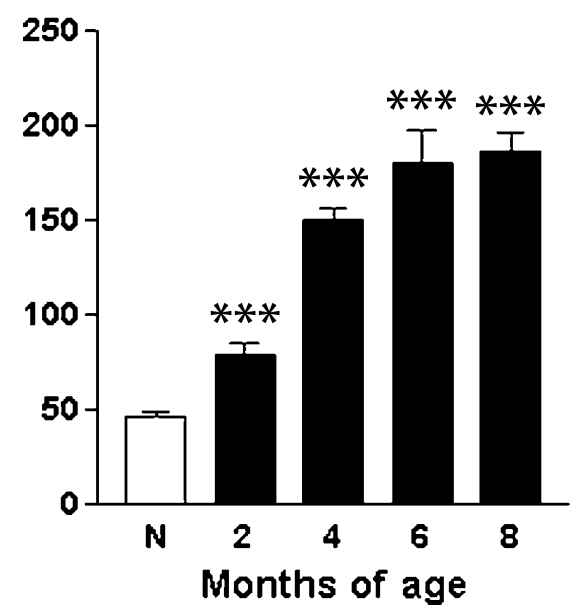

Fig. 5. Expression of p-p38 by mouse kidney cells during diabetic nephropathy. Immunostaining for kidney p-p38 identified increased numbers of glomerular cells (a), tubular cells (b) and interstitial cells (c) expressing p-p38 in streptozotocin-treated diabetic mice compared to normal animals $(\mathrm{N})$. In diabetic

$\mathrm{db} / \mathrm{db}$ mice, greater numbers of glomerular cells (d), tubular cells (e) and interstitial cells (f) were immunostained for p-p38 than in normal mice. Data are means \pm SEM, $n=5-8$, ${ }^{* * *} p<0.001$ vs normal by ANOVA. gcs, glomerular cross sections 

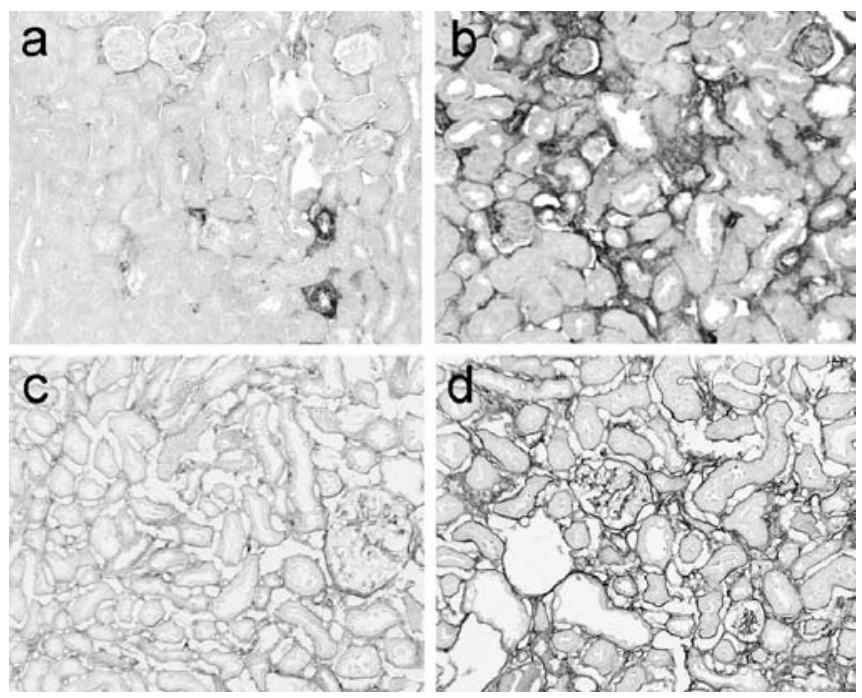

Fig. 6. Increased interstitial fibrosis in streptozotocin-induced diabetic nephropathy in mice. Immunostaining (a) demonstrates the expression of $\alpha$-smooth muscle actin in vessels in a normal mouse kidney. In comparison, $\alpha$-smooth muscle actin is expressed (b) by many interstitial kidney myofibroblasts after 8 months of streptozotocin-induced diabetes. Collagen type IV was identified by immunostaining in the basement membrane (c) of a normal mouse kidney and was markedly increased (d) in the interstitium of a mouse kidney after 8 months of streptozotocin-induced diabetes. Magnification: $\times 160$

Association of p38 mitogen-activated protein kinase signalling with diabetic nephropathy in mice. The development of diabetic nephropathy in streptozotocin-treated mice and obese $\mathrm{db} / \mathrm{db}$ mice has many similarities with the corresponding human diseases. Hyperglycaemia precedes the induction of albuminuria in both these models and $\mathrm{db} / \mathrm{db}$ mice remain obese throughout the progression of their diabetic nephropathy (Table 2).

In both models of diabetic mice, increased kidney levels of p-p38 were detected at the onset of hyperglycaemia and prior to the development of histological renal damage. Blood glucose and $\mathrm{HbA}_{1} \mathrm{c}$ levels correlated with the number of interstitial cells expressing p-p38 in both models (Table 3). In Type 2 diabetic $\mathrm{db} / \mathrm{db}$ mice, kidney $\mathrm{p}-\mathrm{p} 38+$ cells were associated with body weight, but not with serum cholesterol or triglycerides. Albuminuria was strongly associated with interstitial p-p38+ cells in both models but not with glomerular or tubular p-p38+ cells in either model (Table 3). To identify whether the progressive increase in interstitial cells positive for p-p38 immunostaining is linked to the accumulation of myofibroblasts and the development of renal fibrosis, we compared the number of interstitial p-p38+ cells with interstitial immunostaining of $\alpha$-smooth muscle actin (a marker of myofibroblasts) and collagen IV in the streptozotocin-induced model (Fig. 6), which develops renal fibrosis more rapidly than $\mathrm{db} / \mathrm{db}$ mice. We found a strong correlation between the number of in-

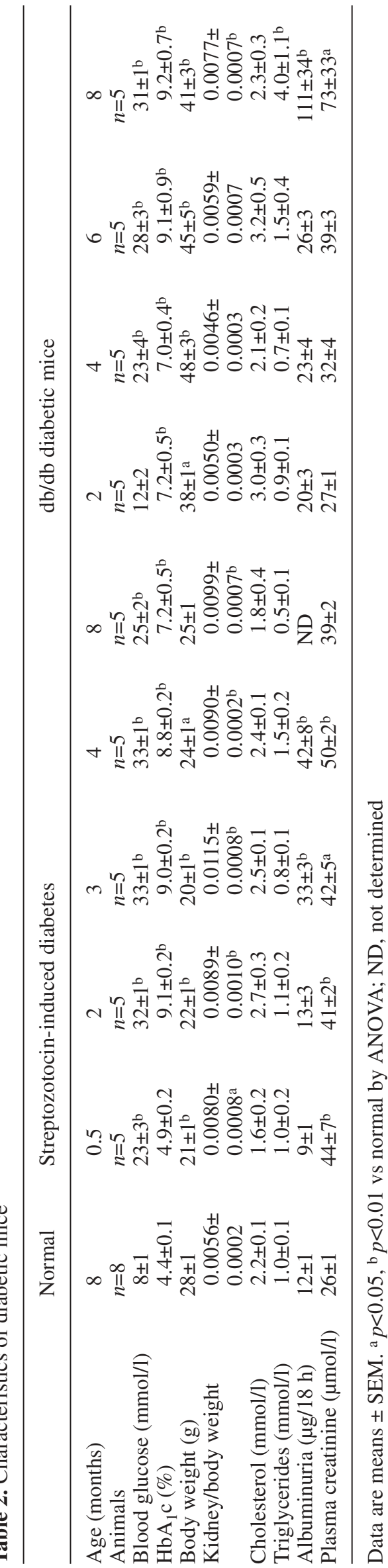


Table 3. Correlation of kidney p-p38+ cells with diabetic state and renal injury

\begin{tabular}{|c|c|c|c|c|c|c|}
\hline & \multicolumn{3}{|c|}{ Streptozotocin-induced diabetes } & \multicolumn{3}{|c|}{$\mathrm{db} / \mathrm{db}$ diabetic mice } \\
\hline & $\begin{array}{l}\text { Glomerular } \\
\text { p-p38 }\end{array}$ & $\begin{array}{l}\text { Tubular } \\
\text { p-p38 }\end{array}$ & $\begin{array}{l}\text { Interstitial } \\
\text { p-p38 }\end{array}$ & $\begin{array}{l}\text { Glomerular } \\
\text { p-p38 }\end{array}$ & $\begin{array}{l}\text { Tubular } \\
\text { p-p38 }\end{array}$ & $\begin{array}{l}\text { Interstitial } \\
\text { p-p38 }\end{array}$ \\
\hline Blood glucose & $0.46, p=0.013$ & $0.36, \mathrm{NS}$ & $0.90, p<0.0001$ & $0.17, \mathrm{NS}$ & $0.72, p<0.0001$ & $0.87, p<0.0001$ \\
\hline $\mathrm{HbA}_{1} \mathrm{c}$ & $0.25, \mathrm{NS}$ & $0.165, \mathrm{NS}$ & $0.88, p<0.0001$ & $0.41, p=0.025$ & $0.74, p<0.0001$ & $0.74, p<0.0001$ \\
\hline Body weight & $-0.66, p<0.0001$ & $-0.55, p=0.0019$ & $-0.54, p=0.0052$ & $0.47, p=0.0094$ & $0.67, p<0.0001$ & $0.56, p=0.0016$ \\
\hline Triglycerides & $-0.031, \mathrm{NS}$ & $0.12, \mathrm{NS}$ & $0.24, \mathrm{NS}$ & $-0.31, \mathrm{NS}$ & $0.058, \mathrm{NS}$ & $0.33, \mathrm{NS}$ \\
\hline Albuminuria & $-0.041, \mathrm{NS}$ & $-0.14, \mathrm{NS}$ & $0.66, p=0.0003$ & $-0.15, \mathrm{NS}$ & $0.19, \mathrm{NS}$ & $0.48, p=0.0083$ \\
\hline Plasma creatinine & $0.29, \mathrm{NS}$ & $0.31, \mathrm{NS}$ & $0.67, p=0.0002$ & $-0.21, \mathrm{NS}$ & $0.076, \mathrm{NS}$ & $0.30, \mathrm{NS}$ \\
\hline
\end{tabular}

Data represent Pearson's coefficient $(r)$ and associated $p$ value

terstitial cells positive for p-p38 immunostaining and the interstitial area of immunostaining for $\alpha$-smooth muscle actin $(r=0.76, p<0.0001)$ and collagen type IV $(r=0.77, p<0.0001)$.

\section{Discussion}

This study demonstrates that increased p38 MAPK signalling is a feature of human and experimental diabetic nephropathy. The kidney localisation pattern of phosphorylated p38 was very similar in human diabetic patients and mouse models, indicating that examination of this signalling pathway in mice is likely to be relevant to the human disease. For this reason, we performed a more detailed analysis in mice to determine if kidney p38 phosphorylation was associated with progression of diabetic renal injury.

In both mouse models, the induction of kidney p38 signalling coincided with the onset of hyperglycaemia and correlated with blood glucose and $\mathrm{HbA}_{1} \mathrm{c}$ levels, indicating that high blood glucose and/or protein glycation may be responsible for directly or indirectly switching on this pathway. In diabetic $\mathrm{db} / \mathrm{db}$ mice, increased numbers of kidney cells positive for p-p38 immunostaining were also associated with body weight, suggesting an additional link to obesity. However, the number of kidney p-p38+ cells in diabetic $\mathrm{db} / \mathrm{db}$ mice did not correlate with blood cholesterol or triglycerides, and obese $\mathrm{db} / \mathrm{db}$ mice with normal blood glucose and $\mathrm{HbA}_{1} \mathrm{c}$ levels had similar numbers of kidney p-p38+ cells to normal animals, which suggests that obesity is unlikely to play an important role in promoting p38 phosphorylation in the kidney in Type 2 diabetic nephropathy. Other pathological features of diabetic nephropathy, such as increased oxidative and osmotic stress, hypertension, cytokine release and renin/angiotensin responses, are also thought to potentially contribute to the induction of kidney p38 signalling [27]. These factors were not evaluated here.
Phosphorylation of p38 was observed in normal human and mouse glomeruli, and increased numbers of glomerular p-p38+ cells were detected in human diabetic renal biopsies and the early stages of mouse Type 1 and 2 diabetic nephropathy. About 20 to $30 \%$ of p-p38+ cells in normal and diabetic human glomeruli were found to be podocytes. These results suggest that p38 signalling may play a role in the maintenance of normal glomerular physiology, presumably by regulating aspects of podocyte function. Over-expression of nephrin in a nephrin-deficient kidney embryonic cell line results in p38 phosphorylation, providing evidence that $\mathrm{p} 38$ has a role in podocyte responses [28]. Increased phosphorylation of $\mathrm{p} 38$ in podocytes during diabetic nephropathy may occur as a direct response to hyperglycaemia or may be an indirect effect of diabetes-induced glomerular endothelial dysfunction or glomerular hypertrophy. Changes to podocyte behaviour mediated by p38 signalling may subsequently contribute to loss of foot processes and proteinuria. However, in our mouse models, we were unable to distinguish p38 phosphorylation in podocytes from other glomerular cells. Instead, we determined the total number of p-p38+ cells within glomeruli. This did not correlate with albuminuria, suggesting that the number of glomerular p-p38+ cells is not related to the mechanisms of proteinuria.

Hyperglycaemia, intraglomerular hypertension and glomerular endothelial dysfunction are also factors which contribute to mesangial hypertrophy and mesangial matrix production in diabetic nephropathy. In diabetic kidneys, we observed increased numbers of cells positive for p-p38 immunostaining within the expanding mesangium. Interestingly, phosphorylation of p38 MAPK signalling occurs in cultured mesangial cells in response to high glucose, an effect which is enhanced by mechanical stretch, angiotensin II, endothelin-1 and platelet-derived growth factor [29]. Angiotensin II and endothelin-1 induce contraction in cultured mesangial cells via p38 MAPK phosphorylation [30, 31]. However, mesangial cell hypertrophy induced by endothelin-1 
is independent of p38 MAPK signalling [32]. High glucose and angiotensin II also promote $T G F-\beta 1$ gene activation in mesangial cells by p38 MAPK signalling [33]. This in turn contributes to fibrosis [7,8]. Thus, an increase in the number of mesangial cells with p-p38 in diabetic kidneys may be an important factor for mesangial remodelling and glomerulosclerosis.

Inflammatory macrophages entering diabetic glomeruli may also promote glomerular injury and mesangial cell p38 phosphorylation. AGE have been shown to induce nuclear factor- $\kappa \mathrm{B}$ activation, inducible nitric oxide synthase expression and nitrite production by macrophages through a pathway dependent on p38 [34]. Secretion of nitric oxide and IL-1 $\beta$ by activated macrophages can subsequently stimulate p38 phosphorylation by mesangial cells $[35,36]$. In this study, we identified glomerular and interstitial macrophages expressing p-p38 in diabetic kidneys, suggesting that diabetes-induced p38 phosphorylation in macrophages may be involved in macrophage-mediated renal injury.

As phosphorylation of $\mathrm{p} 38$ was identified in some epithelial cells within normal kidney cortical tubules, it is possible that p38 signalling plays a role in the maintenance of normal tubular function. This may be related to the constant exposure of renal tubules to hyperosmolar fluid. The numbers of tubular cells positive for p-p38 immunostaining increased acutely at the onset of diabetes and then declined with advancing disease, showing a similar profile to glomerular p-p38+ cells. These comparable glomerular and tubular responses may represent an acute reaction to high amounts of glucose, which is followed by a resetting of glomerular and tubular responsiveness to sugar levels. However, this apparent acute increase and fall in glomerular and tubular p-p38 identified by immunostaining was not evident in our analysis of total kidney p-p38 levels by western blotting. Immunostaining with an amplified system can detect the presence of p-p38 within cells, but cannot determine the level of p-p38. Therefore, comparison of our immunostaining and western blot results suggests that, in advanced disease, the fewer remaining p-p38+ glomerular and tubular cells have high levels of p-p38 or the increased numbers of interstitial cells with p-p38 offset the decline in glomerular and tubular p-p38.

Hyperglycaemia may induce p38 phosphorylation in tubular cells directly or by promoting osmotic stress or injury. High glucose stimulation of cultured proximal tubular epithelial cells results in p38-dependent angiotensinogen production and p38-independent hypertrophy [37, 38]. In addition, high glucose levels can increase the hypertonicity of the tubular fluid, resulting in greater osmotic stress to tubules, which is known to induce p38 phosphorylation in cultured tubular cells [39]. In the current study, dilated tubules in diabetic kidneys appeared to have an increased proportion of p-p38+ cells, suggesting that increased phosphorylation of tubular p38 also occurs in re- sponse to tubular injury. Phosphorylation of p38 in tubular cells can, in turn, promote production of TNF- $\alpha$ and epithelial transdifferentiation into myofibroblasts $[40,41]$, which can subsequently increase interstitial inflammation and fibrosis.

In contrast to glomerular and tubular cells, the number of interstitial cells positive for p-p38 immunostaining increased progressively with the development of mouse Type 1 and 2 diabetic nephropathy, and correlated closely with albuminuria, suggesting an association with renal injury. Myofibroblasts are thought to be the major source of interstitial matrix in diabetic kidneys and their presence correlates significantly with a progressive decline in renal function, and is the best known predictor of progressive diabetic nephropathy [42]. Therefore, we determined whether the number of interstitial p-p38+ cells was associated with myofibroblast accumulation and interstitial fibrosis. Immunostaining for $\alpha$-smooth muscle actin indicated that most p-p38+ interstitial cells in human and mouse diabetic kidneys were myofibroblasts. In streptozotocin-treated mice, the interstitial accumulation of myofibroblasts and collagen type IV showed a highly significant correlation with interstitial p-p38+ cells. Previous in vitro studies have demonstrated that fibroblast proliferation induced by fibroblast growth factor2 and reactive oxygen species is dependent on p38 signalling [43, 44]. In addition, p38 phosphorylation is required for TGF- $\beta$-induced collagen production by fibroblasts [45]. These results suggest that p38 signalling may be important for the development of interstitial fibrosis in diabetic kidneys.

In summary, this study provides evidence that implicates kidney p38 MAPK phosphorylation in the progression of Type 1 and Type 2 diabetic nephropathy. To prove this, however, it will be necessary to conduct further experiments that selectively block phosphorylation of p38 MAPK during the progression of diabetic nephropathy. Long-term administration of a specific p38 MAPK inhibitor to Type 1 diabetic rats has already been shown to prevent neuropathy [46], indicating that similar treatments for diabetic nephropathy are now feasible.

Acknowledgements. This work was supported by a fellowship from the International Society of Nephrology (Laxman Adhikary) and grants from the Australian Kidney Foundation and the National Health \& Medical Research Council of Australia. We thank Lyn Hurst, Tara Robertson, Elyce Ozols and Yingjie Han for their technical support.

\section{References}

1. Ritz E, Tarng DC (2001) Renal disease in type 2 diabetes. Nephrol Dial Transplant 16 [Suppl 5]:11-18

2. Keane WF, Lyle PA (2003) Recent advances in the management of type 2 diabetes and nephropathy: lessons from the RENAAL study. Am J Kidney Dis 41 [3 Suppl 1]: S22-S25 
3. Remuzzi G, Bertani T (1998) Pathophysiology of progressive nephropathies. N Engl J Med 339:1448-1456

4. Raigeaud J, Gupta S, Rogers JS et al. (1995) Pro-inflammatory cytokines and environmental stress cause p38 mitogen-activated protein kinase activation by dual phosphorylation on tyrosine and threonine. J Biol Chem 270:7420 7426

5. Rovin BH, Wilmer WA, Danne M, Dickerson JA, Dixon CL, Lu L (1999) The mitogen activated protein kinase p38 is necessary for interleukin 1beta-induced monocyte chemoattractant protein 1 expression by human mesangial cells. Cytokine 11:118-126

6. Guan Z, Buckman SY, Miller BW, Springer LD, Morrison AR (1998) Interleukin-1beta-induced cyclooxygenase-2 expression requires activation of both c-Jun NH2-terminal kinase and p38 MAPK signal pathways in rat mesangial cells. J Biol Chem 273:28670-28676

7. Chin BY, Mohsenin A, Li SX, Choi AM, Choi ME (2001) Stimulation of pro-alpha(1) (I) collagen by TGF-beta(1) in mesangial cells: role of the p38 MAPK pathway. Am J Physiol Renal Physiol 280:F495-F504

8. Kucich U, Rosenbloom JC, Shen G et al. (2000) TGFbeta1 stimulation of fibronectin transcription in cultured human lung fibroblasts requires active geranylgeranyl transferase 1, phosphatidylcholine-specific lipase C, protein kinase C-delta, and p38, but not erk1/erk2. Arch Biochem Biophys 374:313-324

9. Branger J, van den Blink B, Weijer S et al. (2002) Antiinflammatory effects of a p38 mitogen-activated protein kinase inhibitor during human endotoxemia. J Immunol 168:4070-4077

10. Wada T, Furuichi K, Sakai N et al. (2001) Involvement of p38 mitogen-activated protein kinase followed by chemokine expression in crescentic glomerulonephritis. Am J Kidney Dis 38:1169-1177

11. Stambe C, Atkins RC, Tesch GH et al. (2003) Blockade of $\mathrm{p} 38 \alpha$ MAPK ameliorates inflammatory renal injury in rat anti-GBM glomerulonephritis. J Am Soc Nephrol 14:338351

12. Underwood DC, Osborn RR, Bochnowicz S et al. (2000) SB 239063, a p38 MAPK inhibitor, reduces neutrophilia, inflammatory cytokines, MMP-9, and fibrosis in lung. Am J Physiol Lung Cell Mol Physiol 279:L895-L902

13. Badger AM, Griswold DE, Kapadia R et al. (2000) Disease-modifying activity of SB 242235, a selective inhibitor of p38 mitogen-activated protein kinase, in rat adjuvant-induced arthritis. Arthritis Rheum 43:175-183

14. Wilmer WA, Dixon CL, Herbert C (2001) Chronic exposure of human mesangial cells to high glucose environments activates the p38 MAPK pathway. Kidney Int 60:858-871

15. Daoud S, Schinzel R, Neumann A et al. (2001) Advanced glycation end products: activators of cardiac remodelling in primary fibroblasts from adult rat hearts. Mol Med 7:543-551

16. Yamakawa T, Tanak S, Yamakawa Y et al. (1995) Augmented production of tumour necrosis factor-alpha in obese mice. Clin Immunol Immunopathol 75:51-56

17. Hong SW, Isono M, Chen S, Iglesias-De La Cruz MC, Han DC, Ziyadeh FN (2001) Increased glomerular and tubular expression of transforming growth factor-beta 1, its type II receptor, and activation of the SMAD signaling pathway in the $\mathrm{db} / \mathrm{db}$ mouse. Am J Pathol 158:1653-1663

18. Azar ST, Salti I, Zantout MS, Major S (200) Alterations in plasma transforming growth factor beta in normo-albuminuric type 1 and type 2 diabetic patients. J Clin Endocrinol Metab 85:4680-4682
19. Yeh CH, Sturgis L, Haidacher J et al. (2001) Requirement of p38 and p44/p42 mitogen-activated protein kinases in RAGE-mediated nuclear-kB transcriptional activation and cytokine secretion. Diabetes 50:1495-1504

20. Hsu HY, Chiu SL, Wen MH, Chen KY, Hua KF (2001) Ligands of macrophage scavenger receptor induce cytokine expression via differential modulation of protein kinase signalling pathways. J Biol Chem 276:28719-28730

21. Leonard M, Ryan MP, Watson AJ, Schramek H, Healy E (1999) Role of MAP kinase pathways in mediating IL-6 production in human primary mesangial and proximal tubular cells. Kidney Int 56:1366-1377

22. Weigert C, Sauer U, Brodbeck K, Pfeiffer A, Haring HU, Schleicher ED (2000) AP-1 proteins mediate hyperglycemia-induced activation of the human TGF-beta1 promoter in mesangial cells. J Am Soc Nephrol 11:2007-2016

23. Gruden G, Zonca S, Hayward A et al. (2000) Mechanical stretch-induced fibronectin and transforming growth factor-beta1 production in human mesangial cells is p38 mitogen-activated protein kinase-dependent. Diabetes 49:655661

24. Kang SW, Adler SG, Lapage J, Natarajan R (2001) p38 MAPK and MAPK kinase 3/6 mRNA and activities are increased in early diabetic glomeruli. Kidney Int 60:543-552

25. Jackson AE, Atkins RC, Glasgow EF (1991) Ultrastructural localization of human kidney antigens using monoclonal antibodies. Histochem J 23:509-516

26. Lan HY, Mu W, Nikolic-Paterson DJ, Atkins RC (1995) A novel, simple, reliable, and sensitive method for multiple immuno-enzyme labeling: use of microwave oven heating to block antibody crossreactivity and retrieve antigens. J Histochem Cytochem 43:97-102

27. Tian W, Zhang Z, Cohen DM (2000) MAPK signalling in the kidney. Am J Physiol Renal Physiol 279:F593-F604

28. Huber TB, Kottgen M, Schilling B, Walz G, Benzing T (2001) Interaction with podocin facilitates nephrin signaling. J Biol Chem 276:41543-41546

29. Tsiani E, Lekas P, Fantus IG, Dlugosz J, Whiteside C (2002) High glucose-enhanced activation of mesangial cell p38 MAPK by ET-1, ANG II, and platelet-derived growth factor. Am J Physiol Endocrinol Metab 282:E161-E169

30. Muller E, Burger-Kentischer A, Neuhofer W et al. (1999) Possible involvement of heat shock protein 25 in the angiotensin II-induced glomerular mesangial cell contraction via p38 MAP kinase. J Cell Physiol 181:462-469

31. Sorokin A, Forshi M, Dunn MJ (2002) Endothelin signalling and regulation of protein kinases in glomerular mesangial cells. Clin Sci 103 [Suppl 48]:132S-136S

32. Goruppi S, Bonventre JV, Kyriakis JM (2002) Signaling pathways and late-onset gene induction associated with renal mesangial cell hypertrophy. EMBO J 21:5427-5436

33. Weigert C, Brodbeck K, Klopfer K, Haring HU, Schleicher ED (2002) Angiotensin II induces human-TGF-beta 1 promoter activation: similarity to hyperglycaemia. Diabetologia 45:890-898

34. Wu CH, Huang CM, Lin CH, Ho YS, Chen CM, Lee HM (2002) Advanced glycosylation end products induce NFkappaB dependent iNOS expression in RAW 264.7 cells. Mol Cell Endocrinol 194:9-17

35. Huwiler A, Pfeilschifter J (1999) Nitric oxide stimulates the stress-activated protein kinase p38 in rat mesangial cells. J Exp Biol 202:655-660

36. Guan Z, Buckman SY, Springer LD, Morrison AR (1999) Both p38alpha(MAPK) and JNK/SAPK pathways are important for induction of nitric oxide synthase by interleukin-1 beta in rat glomerular mesangial cells. J Biol Chem 274:3600-3606 
37. Hsieh TJ, Zhang SL, Filep JG, Tang SS, Ingelfinger JR, Chan JS (2002) High glucose stimulates angiotensinogen gene expression via reactive oxygen species generation in rat kidney proximal tubular cells. Endocrinology 143:29752985

38. Hsieh TJ, Fustier P, Zhang SL et al. (2003) High glucose stimulates angiotensinogen gene expression and cell hypertrophy via activation of the hexosamine biosynthesis pathway in rat kidney proximal tubular cells. Endocrinology 144:4338-4349

39. Sheikh-Hamad D, Di Mari J, Suki WN, Safirstein R, Watts BA $3^{\text {rd }}$, Rouse D (1998) p38 kinase activity is essential for osmotic inductions of mRNAs for HSP70 and transporter for organic solute betaine in Madin-Darby canine kidney cells. J Biol Chem 273:1832-1837

40. Meldrum KK, Meldrum DR, Hile KL et al. (2001) p38 MAPK mediates renal tubular cell TNF- $\alpha$ production and TNF-alpha-dependent apoptosis during simulated ischemia. Am J Physiol Cell Physiol 281:C563C570

41. Zhang M, Tang JW, Li XM (2003) Interleukin-1betainduced transdifferentiation of renal proximal tubular cells is mediated by p38-mitogen-activated protein kinase phosphorylation. Zhonghua Yi Xue Za Zhi 83:1161-1165

42. Essawy M, Soylemezoglu O, Muchaneta-Kubara EC et al. (1997) Myofibroblasts and the progression of diabetic nephropathy. Nephrol Dial Transplant 12:43-50

43. Maher P (1999) p38 mitogen-activated protein kinase activation is required for fibroblast growth factor-2-stimulated cell proliferation but not differentiation. J Biol Chem 274:17491-17498

44. Han MJ, Kim BY, Yoon SO, Chung AS (2003) Cell proliferation induced by reactive oxygen species is mediated via mitogen-activated protein kinase in Chinese hamster lung fibroblast (V79) cells. Mol Cells 15:94-101

45. Sato M, Shegogue D, Gore EA, Smith EA, McDeermott PJ, Trojanowska M (2002) Role of p38 MAPK in transforming growth factor beta stimulation of collagen production by scleroderma and healthy dermal fibroblasts. J Invest Dermatol 118:704-711

46. Agthong S, Tomlinson DR (2002) Inhibition of p38 MAP kinase corrects biochemical and neurological deficits in experimental diabetic neuropathy. Ann NY Acad Sci 973:359-362 